\title{
FACTOR DETERMINATION AND REVERSE LOGISTICS MODELLING: THEORY VS. PRACTICE
}

\author{
Slobodan Aćimović ${ }^{9}$, Veljko M. Mijušković ${ }^{10}$ \& Iva Vuksanović Herceg ${ }^{11}$ \\ UDC / UDK: 65.012 .34 \\ JEL classification / JEL klasifikacija: L2 \\ DOI: https://doi.org/10.22598/pi-be/2020.14.1.109 \\ Scientific review / Pregledni znanstveni rad \\ Received / Primljeno: April 1, 2020 / 1. travnja 2020. \\ Accepted for publishing / Prihvaćeno za tisak: May 20, 2020 / 20. svibnja \\ 2020 .
}

\section{Summary}

Reverse logistics management has been the subject of scientific and practical attention for a few decades now. An additional interest for this topic has arisen during the last decade, due to a growing number of business entities it affects and the insight into the strategic potential of adequately managing the reverse logistics flows. Up to now, practical research and empirical confirmation regarding reverse logistics management has been scarce, and the question of defining elements, i.e. factors which determine the reverse logistics flows has remained without a complete answer. In time, various authors have tried to solve this question by setting certain guidelines and models which comprehensively show factors considered to be of key importance for the realization of the reverse logistics flows. The subject of this paper is to analyze in depth such existing models. After defining the very term of reverse logistics, the carried out model analysis respects the dynamic time component, first focusing on the theoretical model in this area- the Carter-Ellram model, and later on to the one empirically confirmed- the contemporary reverse logistics model. The aim of this paper is threefold. First, to explain the evolution of the meaning of reverse logistics. Second, to revise the two approaches which most comprehensively define the set of factors considered to be of most importance for the reverse logistics management. Thirdly, it is necessary to compare the factors identified within the theoretical model, with the ones generated empirically, in order to see the similarities and certain differences among them.

\footnotetext{
${ }^{9}$ Slobodan Aćimović, Ph.D., Full Professor, Belgrade University, Faculty of Economics, Serbia, E-mail: slobodan.acimovic@ekof.bg.ac.rs

${ }^{10}$ Veljko M. Mijušković, Ph.D., Assistant Professor, Belgrade University, Faculty of Economics, Serbia, E-mail: veljko.mijuskovic@ekof.bg.ac.rs

${ }^{11}$ Iva Vuksanović Herceg, Ph.D., Assistant Professor, Belgrade University, Faculty of Economics, Serbia, E-mail: iva.vuksanovic@ekof.bg.ac.rs
} 
Key words: Reverse logistics management, Reverse logistics factors, the Carter-Ellram model, the contemporary reverse logistics model.

\section{INTRODUCTION}

The success of using the reverse logistics activities depends on the adequate defining of the factors which determine it. For that purpose, after defining the very term of reverse logistics and its evolution regarding the scope of activities it covers, an analysis is performed of two chosen models of renowned authors which have been dealing with this issue. The analyzed models follow the determinant of time realization, so the first presented model is the older, theoretical one, followed by the contemporary one, empirically confirmed.

While defining the first model, the so-called Carter-Ellram model, the analysis begins with the influence of the main, natural external factors (the market of inputs, outputs, competitive and regulatory environment) onto the participants of the supply chain. Directing the influence of the mentioned external factors exclusively to the activities of the reverse logistics flows and with their pairing up with the main internal factors, the key factors of influence have been determined ( 9 most relevant factors). Although this model represents a significant scientific contribution, the main shortcoming of this model is its exclusive positioning based on theory, without any practical confirmation (Carter \& Ellram,1998).

The second model (the contemporary reverse logistics model) which is being considered, surpasses this shortcoming. Within it, a check is performed of the validity of key factors identified within the Carter-Ellram model, and then the results are compared with the carried out contemporary empirical research (within which 7 factors of most important influence have been identified) (Huscroft et al., 2013).

The carried out analysis within this paper has several purposes. First of all, it gives a general overview of the definition scope and evolution of the term reverse logistics. Second, two most comprehensive approaches determining the influence onto the realization of the reverse logistics process are being analyzed, in order to identify the main factors. Third, these factors need to be compared in order to identify their similarities and differences, i.e. to separate theory from practice. The stated analysis according to the defined structure follows.

\section{DEFINING AND EVOLUTION OF REVERSE LOGISTICS}

A certain form of interpretation of the term reverse logistics has existed for several decades backwards. However, determining the precise moment of its initial use is not possible to perform with the absolute precision. It can be stated that the evolution in the comprehension of certain logistics flows, in a smaller or greater measure follows the dynamics of the way of thinking and the introduction of the new paradigm in business, as well as within the acts of the participants of the traditional supply chain. 
Therefore, terms such as reverse channels or flows appear within the scientific literature even during the 70 -ies of the XX century and dominantly refers to the activities of recycling (Ginter \& Starling, 1978). One of the earliest broad interpretations of the reverse logistics flows was given by Lambert \& Stock at the beginning of the 80 -ies of the XX century. According to their interpretation, this term refers to "going the wrong way, in a one-way street, since the majority of product shipments flow only from the producer to the customer"(Lambert \& Stock, 1981). Such view point is similar to the one given by Murphy \& Poist defining reverse logistics in 1989 as "the moving of goods from the consumer to the producer through the distribution channel"(Murphy \& Poist, 1989). There is also one very lively interpretation of the term reverse logistics from this period where the stated flows are compared to "moving of the salmon in the process of reproduction since the salmon swims upstream, away from the sea and up to the spring of great rivers" (Thierry et al., 1985).

Based on the stated points of view it can be concluded that during this initial period the importance of reverse logistics flows was not recognized enough and was limited to only certain types of activities, so the reverse flows are at that moment considered as an unusual and rare appearance compared to regular flows within the supply chain. Also, once they are interpreted, the exclusive focus is on the segment of supply chain treating the relationship consumer-producer.

The first formal and wider definition of reverse logistics was given by the Council for Supply Chain Management Professionals (CSCMP) at the beginning of the 90 -ies of the XX century. According to the interpretation of the experts gathered around this institution, the term reverse logistics refers to "the role of logistics in recycling, waste disposal and managing dangerous materials. The wider range of this term includes also all logistics activities connected to the reduction of used resources, exchange, re-usage and materials disposal"(Stock, 1992). Even though this is a wider definition, by analyzing its contents it can be concluded that it is still very general and imprecise, at least according to today`s criteria.

The period of the 90 -ies of the XX century represents a time within which there is an intense interest for the activities of reverse logistics and gradually its potential is comprehended. At this time period, a greater number of individuals and organizations is setting the terms, i.e. own interpretation of this term. Continuing, within Table 1, there is a review of some definitions dating from that time period.

Table 1. The interpretation of the term reverse logistics during the 90-ies of the XX century

\begin{tabular}{|l|l|l|}
\hline $\begin{array}{l}\text { AUTHOR(S) OF } \\
\text { THE } \\
\text { INTERPRETATION }\end{array}$ & INTERPRETATION & $\begin{array}{l}\text { THE SPECIFICS } \\
\text { OF THE } \\
\text { INTERPRETATION }\end{array}$ \\
\hline $\begin{array}{l}\text { Pohlen \& Farris } \\
(1992)\end{array}$ & $\begin{array}{l}\text { The movement of goods from } \\
\text { the producer to the consumer } \\
\text { within the distribution channel. }\end{array}$ & $\begin{array}{l}\text { Limited interpretation, } \\
\text { based dominantly on } \\
\text { marketing principals. }\end{array}$ \\
\hline
\end{tabular}




\begin{tabular}{|l|l|l|}
\hline Kopicky (1993) & $\begin{array}{l}\text { A wider term used for logistics } \\
\text { management, disposal of } \\
\text { hazardous and non-hazardous } \\
\text { materials, which includes both } \\
\text { products, as well as packaging. }\end{array}$ & $\begin{array}{l}\text { Insufficiently precise } \\
\text { interpretation } \\
\text { regarding elements } \\
\text { and activities } \\
\text { encompassed by } \\
\text { reverse logistics. }\end{array}$ \\
\hline $\begin{array}{l}\text { European working } \\
\text { group for reverse } \\
\text { logistics (RevLog) } \\
\text { (1998) }\end{array}$ & $\begin{array}{l}\text { The process of planning, } \\
\text { implementation and control of } \\
\text { the flows of raw materials, semi- } \\
\text { products or finished products } \\
\text { from the place of production, } \\
\text { distribution or usage, up to the } \\
\text { place of returns or adequate } \\
\text { storage. }\end{array}$ & $\begin{array}{l}\text { A well structured } \\
\text { view point with the } \\
\text { clearly defined flow } \\
\text { of action. }\end{array}$ \\
\hline $\begin{array}{l}\text { The process of planning, } \\
\text { implementation and control of } \\
\text { efficient and cost effective flows } \\
\text { of raw materials, semi-products, } \\
\text { finished products, and connected } \\
\text { information from the place of } \\
\text { consumption, to the place of } \\
\text { origin in order to return a part of } \\
\text { the value or to adequately } \\
\text { dispose of the items. }\end{array}$ & $\begin{array}{l}\text { The most complete } \\
\text { definition of this } \\
\text { period with all } \\
\text { relevant elements } \\
\text { included. }\end{array}$ \\
\hline
\end{tabular}

Source: De Brito, M., Dekker, R. (2004), pp. 112-115.

Having revised the various definitions of the term reverse logistics given within Table 1, it can be concluded that in time the definition of the term has grown to be wider, spreading the range of activities and entities incorporated within the reverse channel, thus confirming its growth of importance for the participants within the supply chain. During the contemporary period, dating from the first decade of the XXI century up to now, the interpretation of the reverse logistics flows and activities, besides from pertaining elements which have already been previously identified, is put within the context with two more important characteristics: a) there is a clear basis of reverse logistics on green initiatives; b) the activities of reverse logistics have a strategic component, so their realization can improve the competitive position of the company within the supply chain (Zhang et al. 2018; Wang et al. 2018; Wang et al. 2017).

Talking about the first specifics of the contemporary interpretation of reverse logistics, it is evident that this term, besides the basic association to the reverse movement of flows from the consumer to the producer, has also become a synonym for the reduction of the negative ecological influence within the supply chain. Such an interpretation does not actually represent a surprise, since a great number of reverse logistics activities, such as resource reduction and exchange of materials precisely 
represent unique green efforts (Rogers \& Tibben-Lembke, 2001; Guarnieri et al. 2016). The return of the products and their re-usage decreases the negative effects onto the environment, mainly through waste minimization, excluding resources which still might be used, as well as through the decrease of negative gas emissions within the system of transport and distribution (Georgiadis \& Besiou, 2010; Hjort et al. 2016). Further on, the green basis can also be seen in the return of the partial product value which is present at the end of their life cycle, by reusing components, recycling materials or obtaining the energetic potential from the process of incineration (Kleindorfer et al., 2005). Finally, reverse logistics actions can decrease the client risk during product buying, as well as increase the delivered value (Russo \& Cardinali, 2012).

Focusing on the strategic component within the actual interpretation of reverse logistics, it is stated that today it has a purely critical role in the general strategic positioning of the company. It has already been stated that reverse logistics is being less and less interpreted as the needed expense, and more and more as a way to differentiate the company in the eyes of the client. The efficiency of managing the reverse logistics flows is becoming a part of the corporate image of the companies and an important criteria while selecting suppliers and in further company procurement from those suppliers (Turrisi et al., 2013). The high quality in realization of the reverse logistics promotes long term relationships, both regarding the preferences of the company-buyer, as well as the satisfaction of the final clients. On that basis, the company can achieve a significant competitive advantage, which it would not possess, if there was no adequate interpretation and the valued set of reverse logistics activities (Toffel, 2004).

Concluding the analysis dealing with the interpretation and the evolution of the term reverse logistics, it can be stated that in time its significant evolution and increase of importance have occurred, which is in accordance with the evolution of perceptions of interpreting the relations within the supply chain. That means that the contemporary interpretation of the term reverse logistics corresponds by its elements and principles to the concept of green supply chain management, so these two terms are rightly identified with one another, or the reverse logistics is interpreted as the main dimension of the operationalization of the green supply chain concept. Also, it can be concluded that reverse logistics has a strategic component and importance, so its efficient realization can potentially make the company or the supply chain it belongs to, more competitive.

\section{THE THEORETICAL MODEL OF REVERSE LOGISTICS}

Within a comprehensive theoretical research presented in their paper in 1998, the authors Craig Carter and Lisa Ellram have performed up to then the most detailed review of the professional literature within the field, in order to identify to which degree are the determinants of the reverse logistics known and familiar. While selecting literature, their attention was especially focused on recycling, product re-usage and ecological regulations, as important elements of the process of reverse logistics. This selection comes as no surprise, since during the early period of analyzing these issues, the range of questions dealing with the reverse logistics flows was rather limited and 
precisely mostly connected with these elements. Within the following Table 2 there is a partial presentation of the most important papers needed for the initial construction of the theoretical or the so-called Carter-Ellram model:

Table 2. The partial presentation of the most important papers needed for the initial construction of the Carter-Ellram model

\begin{tabular}{|c|c|c|}
\hline $\begin{array}{l}\text { AUTHOR(S) AND } \\
\text { RESEARCH } \\
\text { THEME }\end{array}$ & $\begin{array}{l}\text { RESEARCH } \\
\text { CONTRIBUTION }\end{array}$ & $\begin{array}{l}\text { RESEARCH } \\
\text { SHORTCOMING(S) }\end{array}$ \\
\hline $\begin{array}{l}\text { Stock (1992)- } \\
\text { Reverse logistics }\end{array}$ & $\begin{array}{l}\text { Comprehensive and multi- } \\
\text { functional view of the } \\
\text { research up to then in the } \\
\text { area of reverse logistics. }\end{array}$ & $\begin{array}{l}\text { Does not offer a well-based, } \\
\text { conceptual framework. }\end{array}$ \\
\hline $\begin{array}{l}\text { Cairncross (1992)- } \\
\text { The European } \\
\text { ecological } \\
\text { regulation, reverse } \\
\text { logistics activities in } \\
\text { Europe }\end{array}$ & $\begin{array}{l}\text { Depicts the effects of the } \\
\text { European regulations onto } \\
\text { the companies doing } \\
\text { business in the ex-EEC, } \\
\text { today's EU. Explains how to } \\
\text { act proactively towards such } \\
\text { regulations. }\end{array}$ & $\begin{array}{l}\text { Does not offer a well-based, } \\
\text { conceptual framework, nor an } \\
\text { empirical confirmation. }\end{array}$ \\
\hline $\begin{array}{l}\text { Bronstad \& Evans- } \\
\text { Correia (1992)- } \\
\text { Specifics of recycled } \\
\text { paper procurement }\end{array}$ & $\begin{array}{l}\text { A detailed description of the } \\
\text { challenges of procuring } \\
\text { recycled paper, with a } \\
\text { comprehensive approach } \\
\text { towards the implementation } \\
\text { of the procurement program } \\
\text { of such a good. }\end{array}$ & $\begin{array}{l}\text { An exclusive focus on the } \\
\text { procurement of the recycled } \\
\text { paper; an attitude is being pointed } \\
\text { out that recycling should be } \\
\text { ranked of higher priority than the } \\
\text { waste prevention, which is not in } \\
\text { accordance with steps of the } \\
\text { ecological hierarchy. }\end{array}$ \\
\hline $\begin{array}{l}\text { Kopicky et al. } \\
\text { (1993)- } \\
\text { The programs of } \\
\text { product re-usage and } \\
\text { recycling }\end{array}$ & $\begin{array}{l}\text { The exploratory research } \\
\text { which uses the combination } \\
\text { of the case study method } \\
\text { and interview in order to } \\
\text { determine the logistics } \\
\text { implications of the product } \\
\text { re-usage and recycling } \\
\text { program. }\end{array}$ & $\begin{array}{l}\text { Does not offer a well-based, } \\
\text { conceptual framework. }\end{array}$ \\
\hline $\begin{array}{l}\text { Drumwright (1994)- } \\
\text { The inter- } \\
\text { organization factors } \\
\text { which influence the } \\
\text { socially responsible } \\
\text { procurement }\end{array}$ & $\begin{array}{l}\text { Enables the initial theory } \\
\text { about the inter- } \\
\text { organizational factors which } \\
\text { influence the ecological } \\
\text { procurement. }\end{array}$ & $\begin{array}{l}\text { It firstly considers the inter- } \\
\text { organizational opposed to external } \\
\text { factors which drive the ecological } \\
\text { procurement. There is a lack of } \\
\text { empirical confirmation. }\end{array}$ \\
\hline
\end{tabular}




\begin{tabular}{|l|l|l|}
\hline $\begin{array}{l}\text { Murphy et al. } \\
\text { (1995)- }\end{array}$ & $\begin{array}{l}\text { Does not offer a well-based, } \\
\text { conceptual framework. It is an } \\
\text { excellent initial research, but it }\end{array}$ \\
$\begin{array}{l}\text { logistics to the } \\
\text { corporate ecological } \\
\text { activism }\end{array}$ & $\begin{array}{l}\text { Enriches the existent } \\
\text { literature with the usage of } \\
\text { an empirical research, using } \\
\text { a priori assumptions. }\end{array}$ & $\begin{array}{l}\text { lements have a direct, empirical } \\
\text { effect onto the level of reverse } \\
\text { logistics activities. }\end{array}$ \\
\hline
\end{tabular}

Source: Carter, C., Ellram, L., (1998), pp. 85-102.

A detailed insight into the papers presented within Table 2, but also into other papers from this period connected with reverse logistics, brings about the following conclusions: the biggest number of carried out researches is focused on general themes, while the specific aspects (such as that one connected to recycled paper for example) are a subject of analysis with only a few papers; the majority of papers have been published in expert, practical journals, rather than those of scientific nature; a small number of papers have a holistic approach to the issue of reverse logistics (with the exception of the paper prepared by Stock, 1992); the entire review of the issue area is of general character, with a significant lack of empirical testing (the exception is the research carried out by Murphy et al., 1995).

Another important insight is that the realization of the reverse logistics process is affected by two groups of factors: those of external character, i.e. from the surroundings, while the others are of internal nature, i.e. generated within one particular company. That is presented within Figure 1.

Figure 1. Factors of influence onto the reverse logistics flows
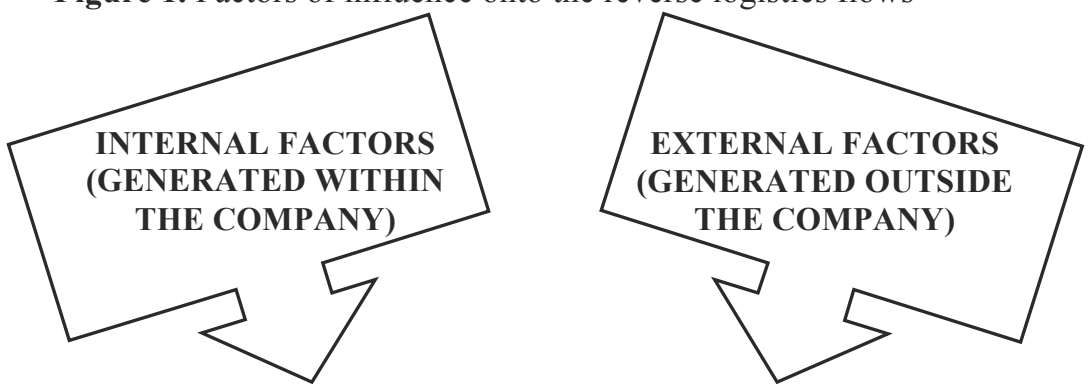

\section{REVERSE LOGISTICS FLOWS}

Source: Carter, C., Ellram, L., (1998), pp. 85-102.

Namely, reviewing literature (especially the paper published by Drumwright, 1994) it is obvious that reverse logistics is significantly affected by inter-organizational factors, such as dedication of the company to ecological issues, the successful 
implementation of ethical standards or the existence of intrapreneurs which have the feeling of expressed dedication to the organizational adoption of the ecologically oriented philosophy. Besides inter-organizational factors, within literature from this period, there is also a recognized direct influence of external elements, such as those coming from the side of the clients, suppliers, competition or state institutions. The identified factors are present within research shown in Table 3.

Table 3. The identified external factors of influence onto the reverse logistics flows

\begin{tabular}{|l|l|}
\hline $\begin{array}{l}\text { EXTERNAL } \\
\text { FACTOR }\end{array}$ & $\begin{array}{l}\text { AUTHOR(S) OF THE RESEARCH WITHIN WHICH THE } \\
\text { FACTOR HAS BEEN IDENTIFIED }\end{array}$ \\
\hline Competition & Stock, 1992; Cairncross, 1992. \\
\hline Clients & $\begin{array}{l}\text { Stock, 1992; Pohlen \& Faris, 1992; Barry et al., 1993; Kopicky et } \\
\text { al., 1993; Livingstone \& Sparks, 1994. }\end{array}$ \\
\hline Suppliers & $\begin{array}{l}\text { Stock, 1992; Pohlen \& Faris, 1992; Bronstad \& Evans-Correia, } \\
\text { 1992. }\end{array}$ \\
\hline $\begin{array}{l}\text { State } \\
\text { institutions }\end{array}$ & $\begin{array}{l}\text { Stock, 1992; Cairncross, 1992; Pohlen \& Faris, 1992; Barry et al., } \\
\text { 1993; Kopicky et al., 1993; Livingstone \& Sparks, 1994; Murphy et } \\
\text { al., 1995. }\end{array}$ \\
\hline
\end{tabular}

Source: Carter, C., Ellram, L., (1998), pp. 85-102.

The authors Carter \& Ellram have started their analysis from the mentioned two big groups of identified factors before the final structuring of the very model. The assumption which the authors have logically set is that internal and external factors are not mutually exclusive, but rather have a joint influence. What is more, their attitude is that the better understanding of the organizational behavior within the company is only possible if it is known whether or not the company is in interaction with its surroundings (Carter \& Ellram, 1998). Even though the authors have not performed an empirical research dealing with the mentioned factors needed to construct their model, their paper is still of vital importance since it presents the most comprehensive analysis of this kind up to that moment. Continuing, following the idea of the authors of the model, before its very presentation, external and internal factors of influence onto the reverse logistics flows are considered.

\subsection{The external factors of influence onto the reverse logistics flows}

The superior company performance is achieved once its strategy corresponds and is compatible to the conditions of the external surroundings. In order to enable the adequate paring up of these elements, the managers firstly must understand how the forces outside the company function. That is precisely why its is the task of the business functions which are most in communication with the surroundings, amongst which logistics assumes an important place, to get to know the influence of that surroundings.

In order to realize their idea, the authors Carter and Ellram have started their analysis with the model of external surroundings influence onto the relations between participants within the supply chains which was defined by Achrol et al., 1983. 
Performing a modification of the model in order to focus it only on the reverse logistics flows, Carter \& Ellram have established a framework for the analysis of elements of external surroundings, which is shown within Figure 2.

Figure 2. The factors of external surroundings of influence onto the reverse logistics flows

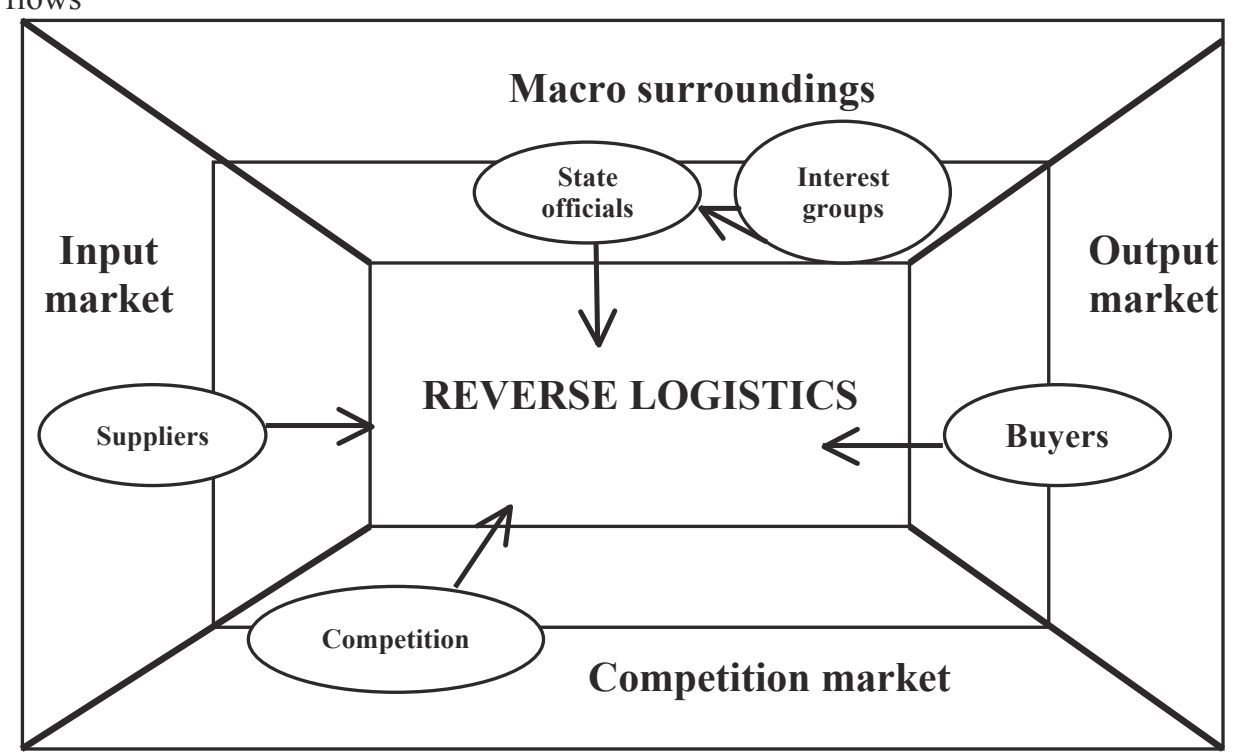

Source: Carter, C., Ellram, L., (1998), pp. 85-102.

According to the presented framework, the direct external surroundings of the company is divided into four parts: the output market, the input market, the competition market and the regulatory surroundings. Also, it can be concluded that the regulatory surroundings consists of state officials, as well as interest groups, such as lobby groups which influence the decisions introduced by the government representatives. Beyond the direct external surroundings there is the so-called macro surroundings, formed of political, legal, economic and social trends onto which an individual company does not have any possibility to influence.

Analyzing in more details the stated elements of the market of external surroundings five most basic, relevant factors of influence onto the reverse logistics flows can be identified. First of all, the review of the literature within the area has shown that a great attention has been paid to the factor of state regulation, since it is an established opinion that it has an extreme influence onto the activities of the reverse logistics flows (Stock, 1992). Currently, the development of legislation which is targeting the green supply chain, and thus the reverse logistics flows is considered to be the milestone and the basic guideline for the development of this area, so it is obvious that there is a continuity in the regard of the importance of this factor. Consequently, 
such state implies the necessity of formal cooperation between the companies within the same industry on the lobbying process and proactive actions compared to state regulatory bodies.

Second, a great number of authors consider that the pressure to create green initiatives is created by final, as well as intermediary clients in form of retailers and that is a significant influence as a particular factor onto the reverse logistics, so it must be analyzed in detail (Straughan et al., 1997). As a result of such an attitude, it is necessary to increase the activities of green marketing and to achieve relations of very close cooperation with retail.

Thirdly, it is expected that the standardized quality and the consistency of the ecologically acceptable inputs shall have a positive influence onto the level of their usage by producers within the supply chain. The ecologically acceptable inputs refer to the procured raw materials, as well as final products which enable the reduction of using particular resources, their re-usage or recycling. However, Bronstad \& Evans-Correia rightfully state that one of the potentially limiting factors of procuring recycled materials is the perception that they are of lower quality (Bronstad \& Evans-Correia, 1992). In order for these attitudes to be avoided or minimized, it is needed for the logistics managers to cooperate with suppliers and other participants within the supply chain, in order to secure high and consistent quality of ecologically tolerant inputs, which also enables the positive influence onto the volume of reverse logistics activities. Regardless of that noticed flow, the quality of inputs is certainly considered an important factor.

Forth, regarding the factor of the competition (within the model set as the communication and vertical coordination between different participants within the supply chain) it can be stated that within the given period of analysis it has been identified as the element of external surroundings of lesser direct influence onto the development of the reverse logistics flows. That is somehow logical, considering the time moment of the model creation. Today, when it is a known fact that the efficient implementation of the reverse logistics flows is not only performed due to the reasons of ecological and social justification, but also as a serious source of competitive advantage, it is extremely important to follow the influence of the competitors within the branch in order to perceive what they focus their core competence on and to adequately answer to their challenges (Mijušković, 2015). It is precisely the influence of the competition, as a specific factor, which can bring about the orientation of the company to focus its expertise on the efficient organization of reverse logistics (Croxton et al., 2001).

Finally, focusing on the factor of ecological uncertainty, an attitude is pointed out that its increase leads to the rise of need for vertical coordination of participants within the supply chain. That means, for example, that the higher level of coordination between buyers and suppliers results in the increased acceptance of new technologies and processes, including the reverse logistics activities. In that manner, an important, indirect influence onto the reverse logistics is confirmed, by the system of communication and vertical coordination. 


\subsection{The internal factors of influence onto the reverse logistics flows}

Besides the factors coming from the external surroundings, the realization of the reverse logistics activities also depends on the series of elements which come directly from the very company. The authors Carter and Ellram within this segment of analysis identify four key factors.

Firstly, it is considered that a true dedication of all interest groups is necessary for the continuous success in the implementation of the system of reverse logistics. Achieving such goal is determined by the development and successful usage of ethical standards which are acceptable for all interest groups (Drumwright, 1994).

Further on, an important question while determining the internal factors is which level of management is dedicated to the incentives of development of the reverse logistics flows. It is an attitude of some authors that this level refers to intrapreneurs (entrepreneurs within a company), which usually belong to the level of middle management (Drumwright, 1994). On the other hand, there are opinions that only the dedication of the company top management is a dominant driver of key undertakings within it (Stock, 1992). It is possible to give an explanation that brings these opposed opinions into some sort of balance. Namely, while the top management support is most important for the establishment of the adequate framework of action, thus the operative segment of the realization is fully dependent on the skillfulness of the middle management layer. The conclusion is that the support of intrapreneurs, as well as company top management, are considered to be irreplaceable factors in securing the political wisdom and the implementation of the reverse logistics process.

Finally, a need has been identified to establish an adequate system of incentives, as the forth internal factor, in order to reward employees for taking actions which contribute to the desired outcomes. Therefore, the logistics managers must develop a system of rewards in order for the employees within the company to recognize the importance of joining the organization of the reverse logistics flows. In case of a different scenario, the activities of the reverse logistics flows could be regarded as a burden and an additional obligation for the employees, which already have overbooked daily schedules, and thus their realization would be on a very suboptimum level (Lambert, 2008).

\subsection{The establishing of the Carter-Ellram model and its critical review}

Taking into consideration all factors of external and internal surroundings analyzed in detail, the authors Carter \& Ellram within the final instance of their analysis have created a comprehensive model which encompasses the key identified elements of influence onto the realization of the reverse logistics flows. The model is presented within Figure 3. 
Figure 3. The Carter-Ellram model

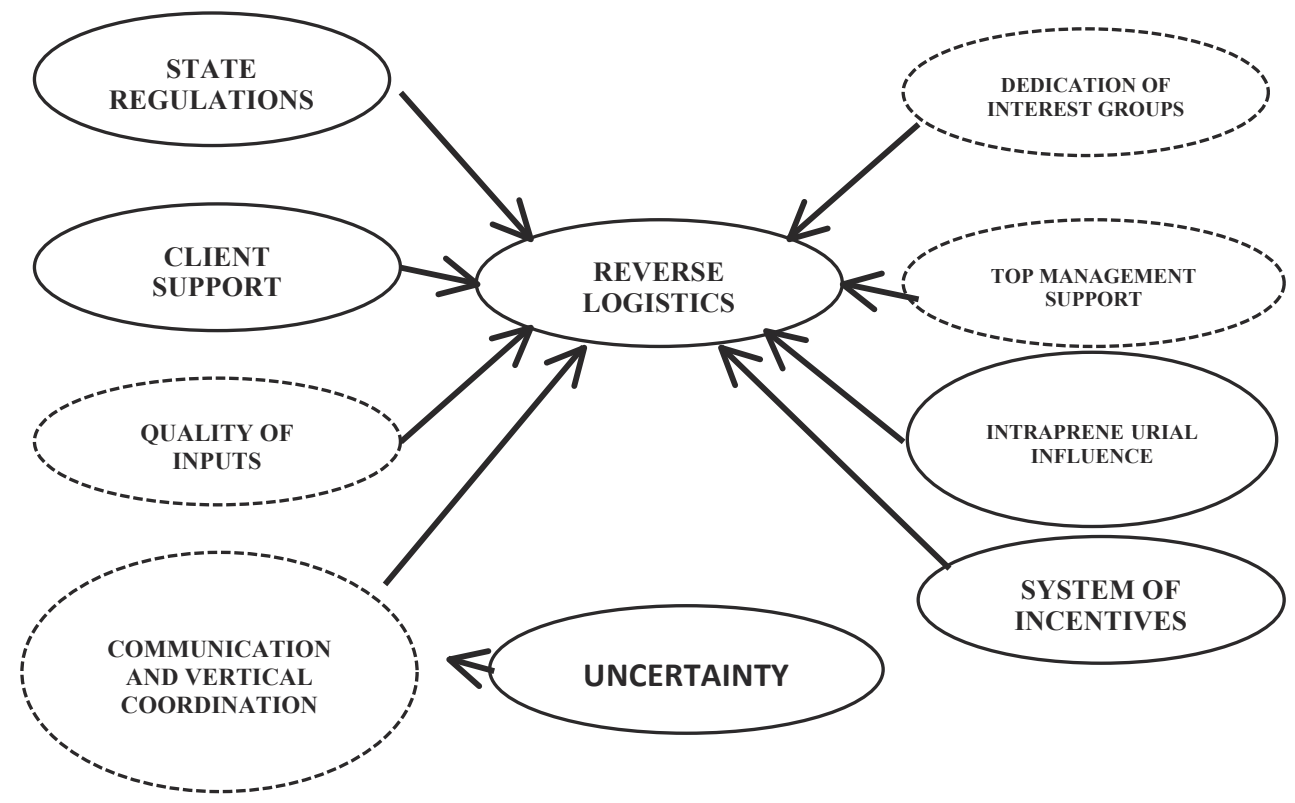

Source: Carter, C., Ellram, L., (1998), pp. 85-102.

Regarding the presented model, in order to understand it better, it must be pointed out that the shapes shown in full line represent the incentive factors upon which the realization of the reverse logistics flows depends on, while the shapes shown in dotted lines symbolize the factors of a limiting nature. The direct incentive factors which come from the external surroundings refer to client support and the pressure of state regulations. Although uncertainty directly influences the rise in the level of communication and vertical coordination between the participants in the supply chain, it only represents an indirect incentive element of the external surroundings onto the reverse logistics flows. The remaining two factors of external surroundings, given in the form of system of communication and vertical coordination, as well as quality of inputs, are considered more as serious limitations, especially if they are not present. Regarding the side of internal factors, as the main incentive element there is the existence of at least one influential intrapreneur, which is personally dedicated and ready to assume responsibility for the realization of the reverse logistics activities. All other internal factors- top management support, dedication of interest groups and the system of incentives- have the nature of limitations.

Giving a critical review of the deeply analyzed Carter-Ellram model, it is necessary to point out its strengths, but also certain weaknesses. Firstly, it can be pointed out that the biggest contribution of this paper is the conceptual framework of 
this pair of authors and the most comprehensive review of literature in order to identify factors which determine the realization of the reverse logistics flows.

Second, the identification of the model factors indicates the close connection and predetermination of both their groups, i.e. external and internal elements. In that manner, its is concluded that these elements are not exclusive but rather compatible. Without external pressure, even the most capable intrapreneurs would not be in the possibility to convince the other company entities to stay personally dedicated to the realization of the reverse logistics flows. On the other hand, without strong internal factors led by top management support, the response to external pressures would lead to minor, reactive changes, without serious dedication and proactiveness in the realization of the green initiatives within the reverse logistics flows.

Thirdly, the knowledge gained within the model represents a good guideline for the managerial decisions. Namely, by determining the internal factors which mostly influence the reverse logistics activities, the company can focus its limited resources onto these areas. On the other hand, the understanding of external drivers secures the right context for the continuous success of the implemented programs. Finally, the authors of the model have foreseen the growth of importance of reverse logistics in the future, so the policies and practice connected to this issue, adopted at the beginning phases of development, would have a wide range of influence in the period to come.

However, besides the numerous advantages that have been pointed out, the Carter-Ellram model has one very serious shortcoming. That shortcoming has to do with basing the analysis and drawing conclusions on a vast, but exclusively theoretical literary review (which is by itself based on a very few practical elements), without empirical testing and the confirmation of the drawn conclusions. Due to that shortcoming it is not possible to be certain whether the identified elements of importance for the reverse logistics have all be identified and are they all important or not. Finally, in existent circumstances it is not possible to compare these factors, i.e. to determine whether some factor is more important than the other.

The stated summary of the importance of the analyzed model, and especially the part that refers to its main shortcoming, is the reason why the next, contemporary model of reverse logistics factors is considered, generated based on empirical research. It is the Huscroft and associates model, with the detail analysis of it following.

\section{THE EMPIRICALLY TESTED REVERSE LOGISTICS MODEL}

The initial period of analyzing the reverse logistics flows as a problem area is characterized by the partial approach to analysis and the insufficient number of expert papers and empirical testings to check the statements presented within these papers. It has already been pointed out that precisely due to such shortcomings, the model comprised by Carter \& Ellram within their paper really does represent the most serious step forward and the positive advancement since the moment of its creation, if not by the empirical confirmation, than by the comprehensiveness of the analysis. 
However, with the passing of the time, since 1998 when the Carter-Ellram model was first devised up to now, there has been a great number of papers treating the reverse logistics flows (Dhanda \& Hill, 2005), as well as the increase of empirically based tests within the area (Mollenkopf et al., 2007). An interesting fact is presented within the research carried out by Stock \& Broadus referring to a clear tendency of the increase in the number of $\mathrm{PhD}$ theses with the empirical research on the topic of reverse logistics on a global level (Stock \& Broadus, 2006). From the previous claims it cannot be concluded in advance that there is a drastic progress, since the scope of issue at stake and connected topics leaves a lot of space for improvements. However, the thing that has been enabled with the improvements within the field of reverse logistics is that certain theoretical grounds were enabled to be checked in practice.

Such situation is the starting point of the analysis within a research carried out by Huscroft and associates in 2013 (Huscroft et al., 2013). The idea which motivated the authors to carry out such a research was that the existence of actual knowledge previously analyzed in literature gave the basis for an advanced knowledge and the direction of future considerations. In that manner past, present and future knowledge about a certain phenomenon are connected. Focusing on the precise subject of research, i.e. the factors for the realization of the reverse logistics flows, Huscroft and associates segmented their research in the following manner: first, they checked the contemporary importance of the identified factors by Carter and Ellram for the analysis of the relevant factors, as the most comprehensive research in the area. Having determined that the Carter-Ellram model represented and adequate structure, i.e. the relevant factors of past, theoretical research in the area of reverse logistics, it was concluded that it can be used as a basis for comparing the research of actual problems in practice connected to the reverse flows. Next, Huscroft and associates carried out an empirical research within which they generated the practically recognized important factors of the reverse logistics flows. The generated factors are the basis for establishing the contemporary reverse logistics model.

\subsection{Generating new factors and comprising the empirically tested reverse logistics model}

The verification of the importance of the factors within the Carter-Ellram model practically created conditions for such a theoretical settings to be the right basis for comparison of reverse logistics factors recognized by the practice as relevant (Lambert, 2008). In order for such factors to be identified, i.e. generated, Huscroft and associates performed an empirical research with this aim.

The empirical research was carried out based on gathering opinions from the managers in the business practice of the USA economy which due to the nature of their business had touch with the reverse logistics flows. The opinion of these managers had to do with the importance of contemporary factors of importance for the realization of the reverse logistics flows, as idenitified in other relevant research in the field (Rogers et al., 2010). The research was carried out using a Delphi technique, as a way of forming the group expert opinion, which usually assumes the cooperation of 5 to 30 participants (Lummus et al., 2005). In this precise case, there were initially 31 managers 
engaged (from the private and state sector), in order for only 18 managers to remain during the entire process, i.e. through all phases of research.

The mentioned phases were carried out through Delphi rounds (usually from 3 to 4) within which the idea was to first identify a certain phenomenon, and then to achieve the concordance of participants concerning their ranking according to the degree of importance. This precise research was carried out through three Delphi rounds, which had the two following results: a) the identified 7 most relevant factors of influence onto the realization of the reverse logistics flows and b) their performed ranking based on importance given by managers-participants of the Delphi technique. The finally ranked key factors of influence onto the reverse logistics flows from the research by Huscroft and associates are given within Table 4.

Table 4. The finally ranked key factors of influence onto the reverse logistics flows from the research by Huscroft and associates

\begin{tabular}{|l|l|l|}
\hline RANK & $\begin{array}{l}\text { FACTORS OF INFLUENCE ONTO THE } \\
\text { REVERSE LOGISTICS FLOWS }\end{array}$ & $\begin{array}{l}\text { WEIGHTED } \\
\text { AVERAGE }\end{array}$ \\
\hline 1 & Client support & 1.17 \\
\hline 2 & Top management support & 2.11 \\
\hline 3 & Developed system of communications & 3.00 \\
\hline 4 & Costs & 4.00 \\
\hline 5 & Process formalization & 5.00 \\
\hline 6 & Timeliness of operations & 5.89 \\
\hline 7 & Ecological issues & 6.83 \\
\hline
\end{tabular}

Source: Huscroft et al., (2013), pp. 304-327.

The interpretation of the identified key factors of influence onto the reverse logistics flows from the research by Huscroft and associates is given within Table 5:

Table 5. The interpretation of the identified key factors of influence onto the reverse logistics flows from the research by Huscroft and associates

\begin{tabular}{|l|l|}
\hline FACTOR & INTERPRETATION \\
\hline Client support & $\begin{array}{l}\text { Refers to the efficient and effective delivery of determined } \\
\text { levels of customer service, the solving of issues concerning } \\
\text { deliveries, product protection and offering constant aid to the } \\
\text { clients. }\end{array}$ \\
\hline $\begin{array}{l}\text { Top management } \\
\text { support }\end{array}$ & $\begin{array}{l}\text { Includes issues connected to the existence of the awareness of } \\
\text { the managerial top about the importance of reverse logistics, the } \\
\text { continuous goal improvement and support expressed in the } \\
\text { form of resources, dedication etc. }\end{array}$ \\
\hline
\end{tabular}




\begin{tabular}{|l|l|}
\hline $\begin{array}{l}\text { Developed } \\
\text { system of } \\
\text { communications }\end{array}$ & $\begin{array}{l}\text { Has to do with the issues of resource visibility, system } \\
\text { integration of participants within the supply chain, timeliness of } \\
\text { updating information and tracing deliveries. }\end{array}$ \\
\hline Costs & $\begin{array}{l}\text { Assumes the existence of the cost-benefit analysis, the financial } \\
\text { metrics, the appreciation of operative costs of the reverse } \\
\text { logistics flows etc. }\end{array}$ \\
\hline $\begin{array}{l}\text { Process } \\
\text { formalization }\end{array}$ & $\begin{array}{l}\text { Refers to the establishment of clearly defined responsibilities, } \\
\text { the standardization of the processes and procedures, as well as } \\
\text { adequate insurance of knowledge for the implementation of the } \\
\text { program. }\end{array}$ \\
\hline $\begin{array}{l}\text { Timeliness of } \\
\text { operations }\end{array}$ & $\begin{array}{l}\text { Treats the demands concerning timely deliveries, service } \\
\text { demands, the time of the operation cycle realization, as well as } \\
\text { the effective usage of the transport possibilities. }\end{array}$ \\
\hline Ecological issues & $\begin{array}{l}\text { Includes the dilemmas concerning recycling, the legal frames of } \\
\text { green initiatives, as well as the practice connected to the } \\
\text { product disposal at the end of its life cycle span. }\end{array}$ \\
\hline
\end{tabular}

Source: Huscroft et al., (2013), pp. 304-327.

Based on all stated, the contemporary reverse logistics created by Huscroft and associates is given within Figure 4.

Figure 4. The contemporary reverse logistics model

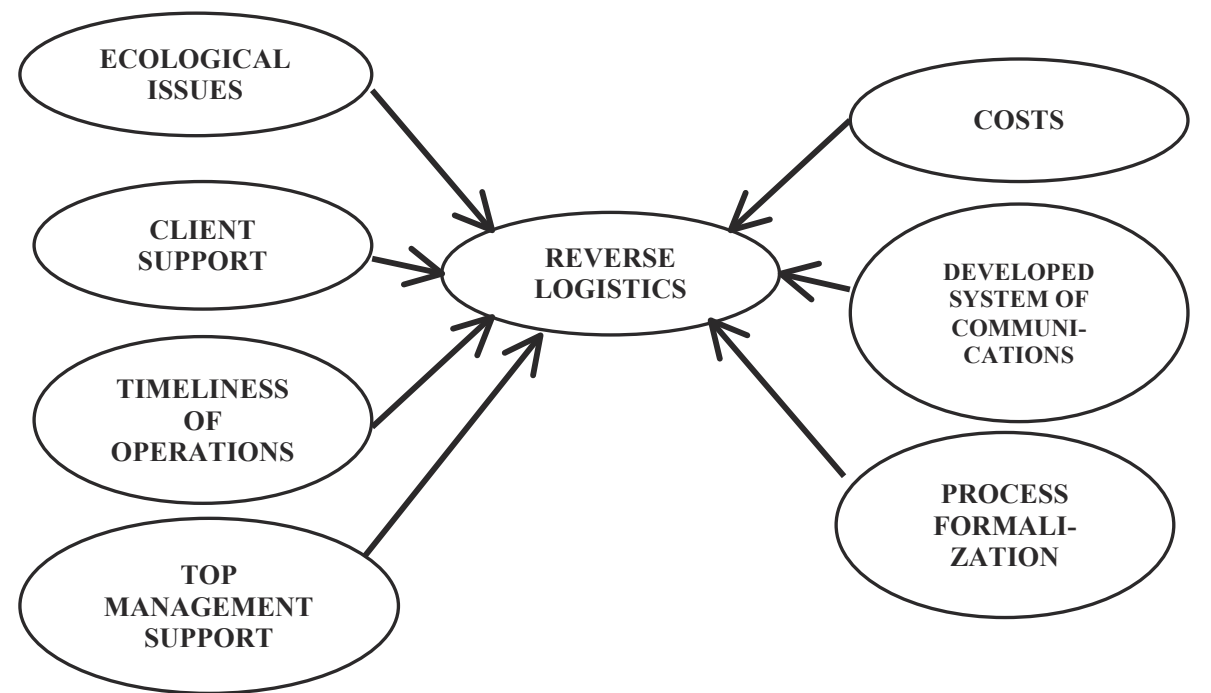

Source: Huscroft et al., (2013), pp. 304-327.

4.2. Critial review of the empirically tested reverse logistics model 
The analysis performed within the Huscroft and associates research and the model created based on the given consideration, represents by far the progress in the theory of reverse logistics flows and the factors which determine its influence. The positive effects of constructing such a model are visible both in the domain of the scientific research and within the business implementation.

Speaking about the scientific research component, it is important to point out the empirical dimension of the model, i.e. the fact that the elements comprising it are not just from theory, but were identified by managers from practice as relevant. The stated empirical research has created the comparison basis for checking the knowledge up to then, mainly based on academic input from people interested in this area of research.

It is important to point out that the analytical skills of these entities have mostly been confirmed by people from practice, which says enough about the quality of their knowledge and perception, as well as the quality of their learning. To be precise, it was concluded that the Carter-Ellram model adequately shows the structure i.e. the relevant factors of past research in the area of reverse logistics and that it can be used as a basis for comparing the research of issues of actual practical problems with the practice dealing with the reverse logistics flows (Haas et al., 2003).

The other important benefit of this created model refers to the practical component, i.e. the improvement of understanding which factors are of critical importance for a more efficient and effective organization of reverse logistics flows within everyday business. Better understanding of importance of particular factors enables the adequate realization of the managerial decision and the allocation of scarce resources.

Besides the positive comments, this research can also be addressed with some concerns and negative critics. They mostly refer to the very methodological procedure of research, i.e. the limited generalization of the conclusions based on the selection of participants of the Delphi research. Namely, the sample structure of the Delphi research only has dominantly present representatives from the state, i.e. military sector. Although some authors (Klapper et al., 1999; Rogers et al., 2010; Rogers and TibbenLembke,1999) including Huscroft and his team believe that the military sector represents the biggest collective supply chain in the world, as well as an important segment of an economy of a country, the dominant presence of participants from only this area can affect the bias in given managerial answers.

Additionally it is an attitude of the authors of this paper that it is better to engage people from the private sector, since they are the main motor and the operative leaders of the reverse logistics flows. At least that is the case when Serbia is involved. However, the very Huscroft and his team have shown with additional testing that the priorities of managers from both private and public sectors are without a noticeable difference, so in a manner this shortcoming is neutralized.

On the other hand, the selection of Delphi survey participants can be seen as a problem from another reason as well. The representatives from practice need not always have the demanded analytical and conceptual knowledge needed to see the wider picture. Thus, two factors more extensively analyzed in theory were not recognized by 
practice. Whether this means that some elements have been neglected or the academic community has at the beginning made a wrong assumption, remains an open question in need of additional attention and interpretation.

Finally, the very authors of the research at one instance revise weather it is good enough to only rely on the Carter-Ellram model, as the good representative of the theoretical analysis within the area and weather that might be the limit of this empirical survey. However, since the research contains the validation of the Carter-Ellram model, it has been confirmed that this should be used as comparative basis for future studies (Huscroft et al., 2013).

\section{THE COMPARATIVE ANALYSIS OF THEORETICAL AND EMPIRICALLY TESTED REVERSE LOGISTICS MODEL}

The first obvious difference between the two models is that the contemporary reverse logistics model does not differentiate the identified factors onto those of external and internal nature, nor does it make a difference between which of them are limiting and which are of stimulative character. One of the important reasons why this is so has to do with the carried out research.

Such differentiation has not been set as a subject of management determination in practice in order not to complicate the process of giving answers but also due to the fact that practitioners within the area maybe can not best determine, i.e. articulate whether some factor is an incentive or a limitation, nor from which surroundings it comes from. Finally, the very Delphi technique is limited only to identifying certain factors, i.e. to achieve a consensus about the importance of their ranking. For additional analyses, the suitable method would be a certain one on one deep interview with the managers, which would secure the research authors a great number of useful, additional information, but would also demand the very survey to be more challenging in terms of time and needed finance. Since the Carter-Ellram model was generated solely based on the theoretical analysis of the problem by the academic experts in the area, the carried out additional differentiations are more than possible and welcome in this case.

Figure 5. shows the comparative analysis depiction of the two analyzed models. 
Figure 5. The relations between factors of the Carter-Ellram model and the contemporary reverse logistics model

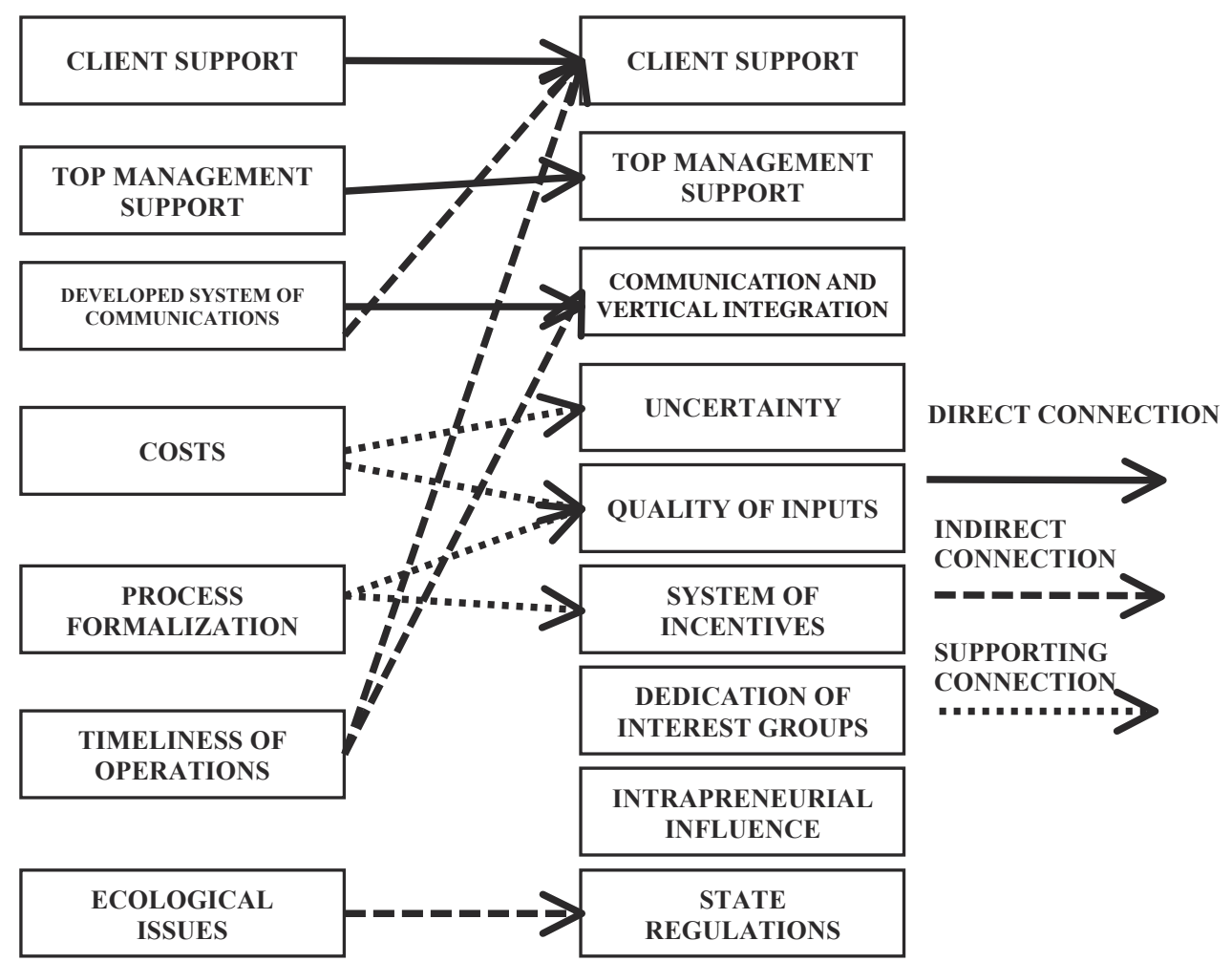

Source: Aćimović, S., Mijušković, V., (2018), pp. 412-423.

Comparing all seven key elements of identified by managers in practice in the contemporary reverse logistics model with the elements of the Carter-Ellram model, several conclusions can be drawn.

First, by analyzing and interpreting the inclusiveness of every factor in particular, it is clear that there is a direct connection between the three most important factors confirmed through practical research carried out by Huscroft and associates with the three factors of the Carter-Ellram model. These factors are: client support, top management support and the developed system of communications. These factors in both analyzed models are compatible, i.e. they have the same comprehension in the regard of interpretation. Finally, as pointed out by Huscroft and associates these factors represent the key topics in literature from the reverse logistics and are needed for almost every business function. While companies strive to answer the demands and client expectations, there must be present a clear and precise support to that process by 
company top management, in which an additional help is presented by the developed process of communications between all relevant participants of the supply chain.

Second, the authors of the research have identified the existence of an indirect connection between three groups of factors of every of the models. Thus, the timeliness of operations is indirectly connected to client support and the system of communication and vertical integration, while there is an indirect connection between these very two factors. Certainly, it is a general attitude that communication is of prime importance when it comes to fulfilling client demands and managing the upstream and downstream relations in the reverse supply chain.

Finally, even though it has been pointed out in a great number of theoretical papers that state regulations which treat the issue of green initiatives within the supply chain represents one of the most determining influences onto its further development, and thus the development of reverse logistics, the American practice has not identified this factor amongst the key factors, while the research authors have determined the existence of only a an indirect connection between the practically recognized ecological issues and that factor.

The reason for such a significant discrepancy between theory and practice may very well be in the previously mentioned fact that practitioners do not have the sufficient level of needed analytical skills to precisely identify and articulate all the influences. Also, another possible explanation is that since the survey has been performed amongst the American managers, their attitude depicts the insufficiently developed function of regulations by which green initiatives are treated, i.e. their inferior position at this part of the world. Of course, the reasons could be completely different than the ones mentioned, but since there are no additional data on the research, i.e. a more detailed feedback from the respondents, the drawing of more decisive conclusions concerning this matter is currently impossible.

Third, two factors (costs and process formalization) do not have neither direct, nor indirect, but only supporting connections to the factors of the Carter-Ellram model. However, since these supporting relations show a certain compatibility of these factors with particular factors of the Carter-Ellram model (with uncertainty, quality of inputs, system of incentives and even with some segments of vertical communication and coordination), the conclusion is that they have a serious potential to be the subject of future research connected to the reverse logistics flows (Dowlatshahi, 2010).

Forth and final remark has to do with the fact that the two factors of the theoretical, Carter-Ellram model do not have any recognition in practice. These factors are the dedication of interest groups and the intrapreneurial influence. Since there is a great number of arguments about the justification of differentiating these factors in theory, which has been neglected by practice at this point, the only interpretation which can be offered is similar to the statements about the potentially insufficient analytics and the narrow perspective of regard, which might have determined the perception of the managers involved in the precise research by Huscroft and associates. 


\section{CONCLUSION}

Summing up the analysis concerning the models of key factors for the usage of the reverse logistics flows several conclusions can be drawn. First of all, various aspects and angles of the reverse logistics defining and evolution were presented. Second, it has been confirmed that the Carter-Ellram model represents the most comprehensive conceptual framework for the insight into theoretical reviews connected to reverse logistics flows since the moment of its creation. Thirdly, the undoubted importance of the contemporary reverse logistics model has been pointed out, as the first and until recently the only empirical confirmation of the theoretically identified factors of importance for the reverse logistics flows. Forthly, it has been shown that there is a partial overlapping and a direct connection between certain elements of the two analyzed models, which have been confirmed by managers in practice to be of the greatest importance. These factors are: client support, top management support and the developed system of communications. That created the basis for some newer research in practice, out of which some have already been realized on a partial, national level (Aćimović, Mijušković, 2018).

\section{REFERENCES}

1. Aćimović, S., Mijušković, V. (2018). Which factors drive the reverse logistics process in practice: Evidence from Serbia. Ekonomika preduzeća, 7-8, pp. 412-423. [doi: 10.5937/EKOPRE1808412A]

2. Achrol, R., Leve, T., Stern, L. (1983). The environment of marketing channels dyads: a framework for comparative analysis. Journal of Marketing, 47, pp. 55-67.

3. Barry, J., Girard, G., Perras, C. (1993). Logistics planning shifts into reverse. Journal of European Business, 5(1), pp. 34-38.

4. Bronstad, G., Evans-Correia, K. (1992). Green Purchasing: The Purchasing Agent's Role in Corporate Recycling. Boston, USA: National Association of Purchasing Management, pp. 122-134.

5. Carter, C., Ellram, L. (1998). Reverse logistics: a review of the literature and framework for future investigation. Journal of Business Logistics, 19(1), pp. 85102.

6. Cairncross, F. (1992). How Europe's companies reposition to recycle. Harvard Business Review, 70(2), pp. 34-45.

7. Croxton, K., Garcia-Dastugue, C., Lambert, D., Rogers , D. (2001). The supply chain management processes. International Journal of Logistics Management, 12(2), pp. 13-36. [doi: 10.1108/09574090110806271]

De Brito, M., Dekker, R. (2004). A framework for reverse logistics. in Dekker, R., Inderfurth, K., van Wassenhove, L., Fleischmann, M. (Eds.) Reverse logistics: quantitative models for closed-loop supply chains, Chapter 1, Berlin: SpringerVerlag. 
8. Dhanda, K., Hill, R. (2005). The role of information technology and systems in reverse logistics: a case study, International Journal of Technology Management, 31(1-2), pp. 140-151.

9. Dowlatshahi, S. (2010), A cost-benefit analysis for the design and the implementation of reverse logistics systems: a case study approach. International Journal of Production Research, 50(5), pp. 1265-1277. [doi: 10.1080/00207540802552642]

10. Drumwright, M. (1994). Socially Responsible Organizational Buying: Environmental Concern as a Noneconomic Buying Criterion. Journal of Marketing, 58(7), pp. 1-19.

11. European working group on reverse logistics (Revlog) (1998). Defining reverse logistics. Brussels, EU: Revlog publishing.

Georgiadis, P., Besiou, M. (2010). Environmental and economical sustainability of WEEE closed-loop supply chains with recycling: a system dynamics analysis. International Journal of Advanced Manufacturing Technology, 47, pp. 475-493. [doi: 10.1007/s00170-009-2362-7]

Ginter, P., Starling, J. (1978). Reverse distribution channels for recycling. California Management Review, 20(3), pp. 72-81.

Guarnieri, P., e Silva, L. C., \& Levino, N. A. (2016). Analysis of electronic waste reverse logistics decisions using Strategic options development analysis methodology: A Brazilian case. Journal of Cleaner Production, 133, 1105-1117

Guarnieri, P., de Silva, L. C., Levino, N. A. (2016). Analysis of electronic waste reverse logistics decisions using Strategic options development analysis methodology: A Brazilian case. Journal of Cleaner Production, 133(2), pp. 1105-1117. [doi: 10.1016/j.jclepro.2016.06.025]

12. Haas, D., Murphy, F., Lancioni, R. (2003), Managing reverse logistic channels with data envelopment analysis. Transportation Journal, 43(3), pp. 59-69. [doi: $10.12691 /$ jbms-1-5-4]

13. Hjort, K., Lantz, B. (2016). The impact of return policies onto profitability: A fashion e-commerce case. Journal of Business Research, 69(11), pp. 4980-4985. [doi: 10.1016/j.jbusres.2016.04.064]

14. Huscroft, J., Hazen, B., Hall, D., Skipper, J., Hanna, B. (2013). Reverse logistics: past research, current management issues, and future directions. The International Journal of Logistics Management, 24(3), pp. 304-327.

15. Klapper, L., Hamblin, N., Hutchinson, L., Novak, L., Vivar, J. (1999). Supply Chain Management: A Recommended Performance Measurement Scorecard. McLean, VA, USA: Logistics Management Institute.

Kleindorfer, P., Singhal, K., Van Wassenhove, L. (2005). Sustainable operations management. Production and Operations Management, 14(4), pp. 482-492.

Kopicky R., Berg, M., Legg, L., Dasappa, V., Maggioni, C. (1993). Reuse and Recycling: Reverse Logistics Opportunities. Oak Brook, Illinois, USA: Council of Logistics Management.

16. Lambert, D. (2008). Supply chain management: processes, partnership, performance. $3^{\text {rd }}$ edition. Sarasota, USA: Supply Chain Management Institute. 
Lambert, D., Stock, R. (1981). Strategic Physical Distribution Management. Homewood, USA: Irwin.

Livingston, S., Sparks, L. (1994). The new German packaging laws: effects on firms exporting to Germany. International Journal of Physical Distribution and Logistics Management, 24(7), 15-25.

17. Lummus, R., Vokurka, R., Duclos, L. (2005). Delphi study on supply chain flexibility. International Journal of Production Research, 43(13), pp. 2687-2708. [doi: 10.1080/00207540500056102]

18. Mijušković, V. (2015). Ključni koncepti nove paradigme u lancu snabdevanja. Ekonomske ideje i praksa, 19, pp. 49-64.

19. Mollenkopf, D., Russo, I., Frankel, R. (2007). The returns management process in supply chain strategy. International Journal of Physical Distribution and Logistics Management, 37(7), pp. 568-592. [doi: 10.1108/09600030710776482]

Murphy, P., Poist, R. (1989). Management of Logistical Retro-movements: An Empirical Analysis of Literature Suggestions. Transportation Research Forum, 29(1), pp. 177-184.

20. Murphy, P., Poist, R., Braunschweig, C. (1995). Role and Relevance of Logistics to Corporate Environmentalism: An Empirical Assessment. International Journal of Physical Distribution and Logistics Management, 25(2), pp. 5-19.

21. Pohlen, T., Farris, M. (1992). Reverse logistics in plastics recycling. International Journal of Physical Distribution \& Logistics Management, 22(7), pp. 35-47.

Rogers, D., Tibben-Lembke, R. (2001). An examination of reverse logistic practices. Journal of Business Logistics, 22(2), pp. 129-148. [doi: 10.1002/j.21581592.2001.tb00007.x]

22. Rogers, D., Rogers, Z., Lembke, R. (2010), Creating value through product stewardship and take back, Sustainability, Accounting, Management and Policy Journal, 1(2), pp. 133-160. [doi: 10.1108/20408021011089211]

23. Rogers, D., Tibben-Lembke, R. (1999), Going backwards: reverse logistics trends and practices. Pittsburg, USA: Reverse Logistics Executive Council Press.

Russo, I., Cardinali, S. (2012). Product returns and customer value: a footware industry case. in Jodlbauer, H., Olhager, J., Schonberger, R. (Eds.) Modeling Value: Contribution to management science, part 2. Berlin: Springer.

24. Stock, J. (1992). Reverse Logistics. Oak Brook, Ilinois, USA: Council of Logistics Management.

25. Stock, J., Broadus, C. (2006). Doctoral research in supply chain management and/or logistics-related areas: 1999-2004. Journal of Business Logistics, 27(1), pp. 139-496. [doi:10.1002/j.2158-1592.2006.tb00244.x]

26. Straughan, R., Roberts, D., James, A. (1997). Environmental segmentation alternatives: a look at green consumer behavior in the new millennium. The Journal of Consumer Marketing, 16(6), pp. 558-575.

Thierry, M., Salomon, M., Van Nunen, J., Van Wassenhove, L. (1985). Strategic issues in product recovery management. California Management Review, 37(2), pp. 114135 . 
Toffel, M. (2004). Strategic management of product recovery. California Management Review, 48(2), pp. 120-141. [doi:10.2307/41166214]

Turrisi, M., Bruccoleri, M., Cannella, S. (2013). Impact of reverse logistics on supply chain performance. International Journal of Physical Distribution and Logistics Management, 43(7), pp. 564-585. [doi:0.1108/IJPDLM-04-2012-0132]

Wang, X., Mingming Zh., Honghoui H. (2018). Reverse Logistic Network Optimization Research for Sharing Bikes. Procedia Computer Science, 126(5), pp. 1693-1703. [doi:10.1016/j.procs.2018.08.108]

Wang. J., Chen, H., Rogers, D., Ellram, L. (2017). A bibliometric analysis of reverse logistics research (1992-2015) and opportunities for future research. International Journal of Physical Distribution and Logistics Management, Vol. 47(8), pp. 666687. [doi: 10.1108/IJPDLM-10-2016-0299]

Zhang, Y., Tianshan, M., Faheem Ud Din, M. (2018). The Impact of Reverse Logistics on Operational Performance. American Journal of Mechanical and Industrial Engineering, 3(5), pp. 99-104. [doi: 10.11648/j.ajmie.20180305.14] 


\title{
ODREĐIVANJE ČIMBENIKA I MODELIRANJE LOGISTIKE POVRATA: TEORIJA VS. PRAKSA
}

\author{
Slobodan Aćimović, Veljko M. Mijušković \& Iva Vuksanović Herceg
}

\begin{abstract}
Sažetak
Upravljanje logistikom povrata predmet je pozornosti znanstvenika $i$ praktičara već nekoliko desetljeća unatrag. Povećani interes za ovu temu javio se posljednjeg desetljeća uslijed sve većeg broja poslovnih subjekata na koje ona utječe, kao i uvida u strateški potencijal adekvatnog upravljanja tijekovima logistike povrata. Do sada, praktična istraživanja i empirijska potvrda u pogledu upravljanja logistikom povrata bili su rijetki, a pitanje definiranja elemenata tj. čimbenika tijekova logistike povrata ostalo je bez potpunog odgovora. Protekom vremena različiti autori pokušali su riješiti ovo pitanje postavljajući određene smjernice i modele koji sveobuhvatno ukazuju na čimbenike za koje se vjeruje da su od ključne važnosti za realizaciju tijekova logistike povrata. Predmet ovog rada jest dubinska analiza takvih postojećih modela. Nakon definiranja samog pojma logistike povrata, provedena analiza modela uvažava dinamičku vremensku komponentu, prvo se usredotočujući na teorijski model $u$ području - Carter-Ellram model, a zatim na onaj empirijski potvrđen - suvremeni model logistike povrata. Cilj ovog rada je trostruk. Prvo, objasniti evoluciju u značenju logistike povrata. Drugo, revidirati dva pristupa koja na najcjelovitiji način identificiraju čimbenike koji se smatraju od najveće važnosti za upravljanje logistikom povrata. Treće, usporediti čimbenike prvog, teorijskog modela, s onima koji su dobiveni empirijski, kako bi se vidjele sličnosti i razlike između njih.
\end{abstract}

Ključne riječi: Upravljanje logistikom povrata, Čimbenici logistike povrata, Carter-Ellram model, Suvremeni model logistike povrata. 